( Валентина Чоп'як, Христина Ліщук-Якимович, Роман Пукаляк, 2020

doi:10.37321/immunology.2020.3-4-05

удк: 612.017:615.834:615.83+615.34:547:616.24

\title{
ДОСЛІДЖЕННЯ ПОКАЗНИКІВ ІМУНІТЕТУ НА МОДЕЛІ БРОНХІАЛЬНОЇ АСТМИ У ЛАБОРАТОРНИХ ТВАРИН (ЩУРИ) ПРИ ДІЇ СТАНДАРТИЗОВАНОГО ЕКСТРАКТУ ЛИСТЯ РЕЛІКТОВОГО ДЕРЕВА ГІНКГО ДВОЛОПАТЕВОГО
}

\author{
КУЗНЄЦОВА Л.В. ${ }^{1}$, ЛІТУС В.І. ${ }^{1}$, БАБАДЖАН В.Д. ${ }^{2}$, ЮРКІНА А. В. ${ }^{1}$, \\ НАЗАР О.В. ${ }^{1}$, БОНДАРЕНКО Т.М. ${ }^{1}$, КУЗНЄЦОВ О.Г. ${ }^{1}$ \\ ${ }^{1}$ Національна медична академія післядипломної освіти (НМАПО) імені П. Л. Шупика, Київ \\ ${ }^{2}$ Харківський національний медичний університет
}

\section{Вступ}

На відміну від численних випадків хвороби у людини, алергічна астма не розвивається в тваринному світі, тому виникає необхідність виявлення декількох характерних ознак астми у тварин. Існує кілька варіантів первинної сенсибілізації в залежності від концентрації алергену (Andersson P., 1980) [10]. При цьому ще одним із обмежуючих факторів є складність отримання досліджуваного матеріалу (бронхоальвеолярний лаваж (БАЛ), периферична кров) і його обмеженість у порівнянні з людським. Про дослідження подібного роду є лише поодинокі повідомлення [7, 8]. Найбільш адекватна модель алергічного запалення спостерігається у морських свинок, тому що даний вид тварин здатний до зовнішніх проявів ознак, характерних для розвитку алергічного запалення.

Останні 20-30 років характеризуються ростом захворюваності і тяжкості перебігу процесу бронхіальної астми (БА), яка розвивається на тлі хронічного обструктивного захворювання легень (ХОЗЛ). За соціальною значимістю цей патологічний стан виходить на одне з перших місць серед захворювань органів дихання [1, 2, 3, 9, 12]. Дослідження останніх років показали, що симптоми бронхообструкції, як правило, з'являються одночасно з симптомами інфекції і залишаються після одужання, загострюючись при наступній інфекції [1, 3, 4, 5].

Багато авторів припускають $[1,2,3,4,7,9$, $11,12]$ наступні варіанти взаємодії алергії та інфекції при БА і ХОЗЛ - це інфікування бактеріями бронхіального дерева, що призводить до формування бактеріальної алергії, яка не до кінця відомими нам механізмами викликає напади задухи і запалення бронхів, що полегшує проникнення в тканини неінфекційних алергенів, при цьому інфекція виступає як провідник неінфекційної сенсибілізації. Різноманітність взаємин інфекційного запального і істинного алергічного механізмів призводить до складної патогенетичної картини БА і ХОЗЛ, в якій провідну роль несе імунна система організму $[4,5,6]$.
Для діагностики, адекватного лікування та відповіді на терапію хворих на бронхіальну астму та хронічного обструктивного захворювання легень провідну роль відіграє її неоднорідність - ця неоднорідність позначається поняттям «фенотип бронхіальної астми». Фенотип БА і ХОЗЛ позначає сукупність ознак захворювання, сформованих на основі генетичних особливостей людини під впливом факторів зовнішнього середовища. Хворі із різними фенотипами астми по-різному відповідають на одну і ту ж схему лікування. У міру відкриття і розробки фенотипспецифічної терапії, з'являються можливості перевести перебіг астми з важкого в більш легкий.

\section{Матеріали і методи.}

В основу нашого дослідження взята модель бронхіальної астми (БА) по Р. Andersson (1980) [10]. Об'єктом дослідження взята група із 60 білих щурів - самців вагою 180-200 грамів. 40 щурів 2 дні підряд сенсибілізували внутрішньочеревинним введенням 100 мкл фізіологічного розчину, що містить 20 мкг овальбуміну (ОА) і 2 мг гідроксиду алюмінію. На 24, 25 і 26-й дні щурів поміщали у камеру і піддавали дії аерозолю - 1\%-го овальбуміну у фізіологічному розчині впродовж 20 хв. [7, 8, 10, 12, 13]. На моделі БА досліджували дію на лабораторних тваринах стандартизованого екстракту листя реліктового дерева гінкго дволопатевого (СЕГД). Після 2-кратної сенсибілізації щурам з 1-ої по 24 добу вводили через рот водний екстракт СЕГД (препарат “Танакан”, Beafour Ipsen, Франція) у дозі 20 мг/кг/добу.

Після закінчення останньої інгаляції імунізованих і інтактних тварин забивали і досліджували реакції клітинного і гуморального імунітету.

Тестування рівня клітинних реакцій імунітету у тварин проводили, використовуючи виділені 3 крові у градієнті фіколл-пак (1.077) лімфоцити. Застосовували середовище Ігла, збагачену L-глютаміном і 5\% ембріональною телячою сироваткою (усі реактиви фірми Serva, Німеччина). 
Усі тварини були розподілені на три групи (20 тварин у кожній групі): 1 група - контрольні (інтактні) тварини; 2 група - дослідні тварини з модельованою алергією в дихальних шляхах; 3 група - дослідні тварини 3 модельованою алергією, які проліковані СЕГД перед введенням дозволяючої дози алергену (1\% овальбуміну).

\section{Результати.}

Вміст формених елементів, представлений у таблиці 1 досліджених клітин крові, звертають на себе увагу флуктуації кількості еозинофілів і паличкоядерних лейкоцитів. Перші достовірно збільшувалися у період моделювання процесу і мало змінювалися у кількісному плані при проведенні експериментальної терапії, тоді як кількість паличкоядерних лейкоцитів знижувалася у тварин 2 і 3 груп. Коливання у вмісті сегментоядерних лейкоцитів, моноцитів і лімфоцитів були незначними в усіх групах $[1,2,3$, $4,5,13]$.

\section{Модель аллергического бронхоспазма по Andersson (1980) с применением СэГБ (єТанакан», Beafour Ipsen, Франция) в дозе20мr/kт}

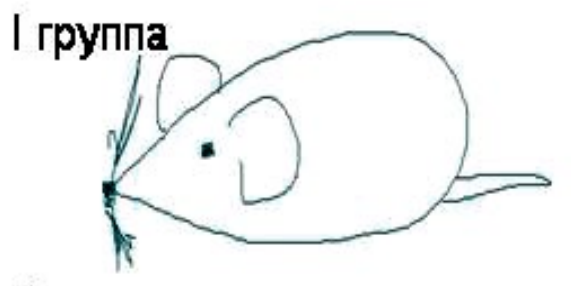

II группа

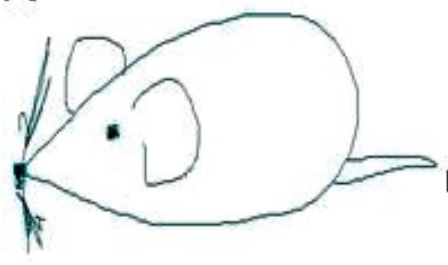

2-х кратная сенсибилизация внутрибрюшинным введением

20мкг овапьбумина и 2мг гидроксида алюминия в 100 мкл физ.р-ра

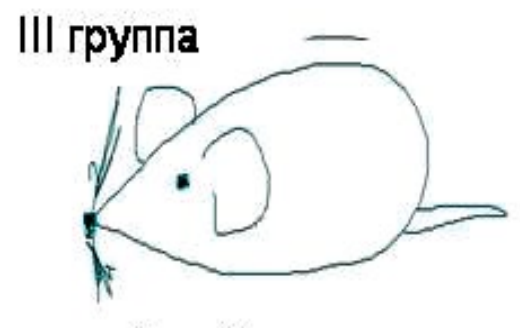

Сенсибипизация

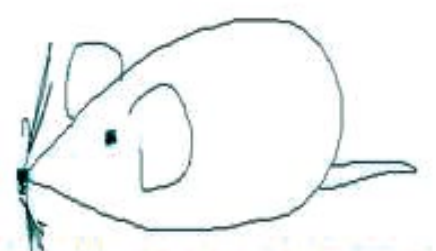

Baedenue per os sodnozo эkempakma CэГБ в doze 20 melkefymau c 1 mo 24 cymku
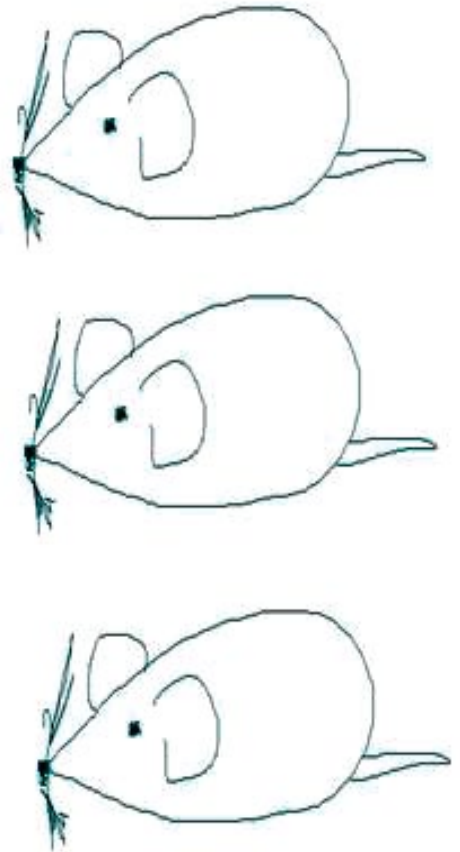

3-х кратная ингапяция алпергена - $1 \%$ аэрозоля овальбумина на 24,25,26 сутки

Вміст формених елементів «білої» крові у тварин різноманітних груп (M \pm m)

\begin{tabular}{|l|l|l|l|l|l|}
\hline \multirow{2}{*}{\multicolumn{1}{|c|}{ Групи }} & \multicolumn{5}{|c|}{ Відносний вміст клітин, \% (середнє значення) } \\
\cline { 2 - 6 } & Паличкоядерні & \multicolumn{1}{|c|}{ Сегментоядерні } & \multicolumn{1}{|c|}{ Моноцити } & \multicolumn{1}{|c|}{ Лімфоцити } & Еозинофіли \\
\hline Інтактні тварини & $4,1 \pm 0,01$ & $12,1 \pm 0,01$ & $3,8 \pm 0,03$ & $75,8 \pm 0,07$ & $4 \pm 0,01$ \\
\hline $\begin{array}{l}\text { 2. Сенсибілізовані тварини, які } \\
\text { не лікуються }\end{array}$ & $0,8^{\star} \pm 0,01$ & $13,5 \pm 0,06$ & $1,8 \pm 0,01$ & $76,3 \pm 0,07$ & $7,3 \pm 0,05$ \\
\hline $\begin{array}{l}\text { 3. Сенсибілізовані } \\
\text { тварини, які отримували СЕГД }\end{array}$ & $1,3^{\star} \pm 0,05$ & $9,8 \pm 0,05$ & $2,0 \pm 0,02$ & $77,1 \pm 0,06$ & $9,8 \pm 0,04$ \\
\hline
\end{tabular}

Примітка: *-достовірно $(p<0,05)$ по відношенню до контролю. 
Дослідження фагоцитарної активності клітин периферичної крові щурів показало, що фагоцитарне число мало стійку тенденцію до зниження у тварин з модельованою алергією, як при проведенні експериментальної терапії, так і без неї (таблиця 2). При обчисленні фагоцитарного індексу виявлені аналогічні, але достовірні зміни $(p<0,05)$.

Можна зробити висновок, що, незважаючи на відсутність змін в кількісній характеристи- ці клітин, що фагоцитують, при модельованій алергії (моноцити, сегментоядерні лейкоцити), функціональна активність цих клітин в умовах сенсибілізації може змінюватися, про що свідчать достовірні зміни у рівні фагоцитарного індексу $[1,2,4,5,6,9]$.

Збільшення числа загальної кількості лейкоцитів у тварин з модельованою алергією в дихальних шляхах свідчить на користь думки про запальну природу модельного алергічного процесу.

Таблиця 2

Фагоцитарна активність клітин крові у тварин різних груп (M \pm m)

\begin{tabular}{|l|c|c|}
\hline \multicolumn{1}{|c|}{ Групи } & Фагоцитарне число & Фагоцитарний індекс \\
\hline 1. Інтактні тварини & $90 \pm 0,2$ & $11,9 \pm 0,1$ \\
\hline 2. Сенсибілізовані тварини, які не лікуються & $77 \pm 0,3$ & $7,8^{\star} \pm 0,3$ \\
\hline 3. Сенсибілізовані тварини, які отримували СЕГД & $69 \pm 0,4$ & $7,2^{\star} \pm 0,2$ \\
\hline
\end{tabular}

Примітка: * достовірно $(p<0,05)$ по відношенню до контролю.

Разом з дослідженням клітинної неспецифічної активності (фагоцитоз і природний кіллінг) було вивчено стан специфічних клітинних реакцій у тварин різних груп. Для цього досліджували активність специфічних кілерів крові відносно курячих еритроцитів, «навантажених» овальбуміном за допомогою танінової кислоти. Другим методичним прийомом вивчення специфічних клітинних реакцій було дослідження активності продукції фактору гальмування міграції макрофагів (ФГМ) при контакті лімфоцитів крові щурів з овальбуміном in vitro. Наявність ФГМ в супернатантах визначали у непрямому капілярному тестуванні гальмування міграції перитонеальних макрофагів інтактних тварин [1, 5, 6, 9].
Сенсибілізація тварин овальбуміном супроводжувалася істотним підвищенням (більш ніж у 6 разів) цитолітичної активності клітин крові у порівнянні із контролем (рис. 1). Проведення експериментальної терапії сприяло достовірному $(p<0,01)$ зниженню рівня деструктивної активності клітин крові тварин. Ці дані дозволяють вважати, що в умовах алергічного процесу у дихальних шляхах, викликаного багатократним введенням овальбуміну, істотна роль належить специфічним цитолітичним реакціям. Застосування препаратів СЕГД, хоча не привело до повної нормалізації (до рівня інтактних тварин), проте сприяло зниженню сенсибілізації.

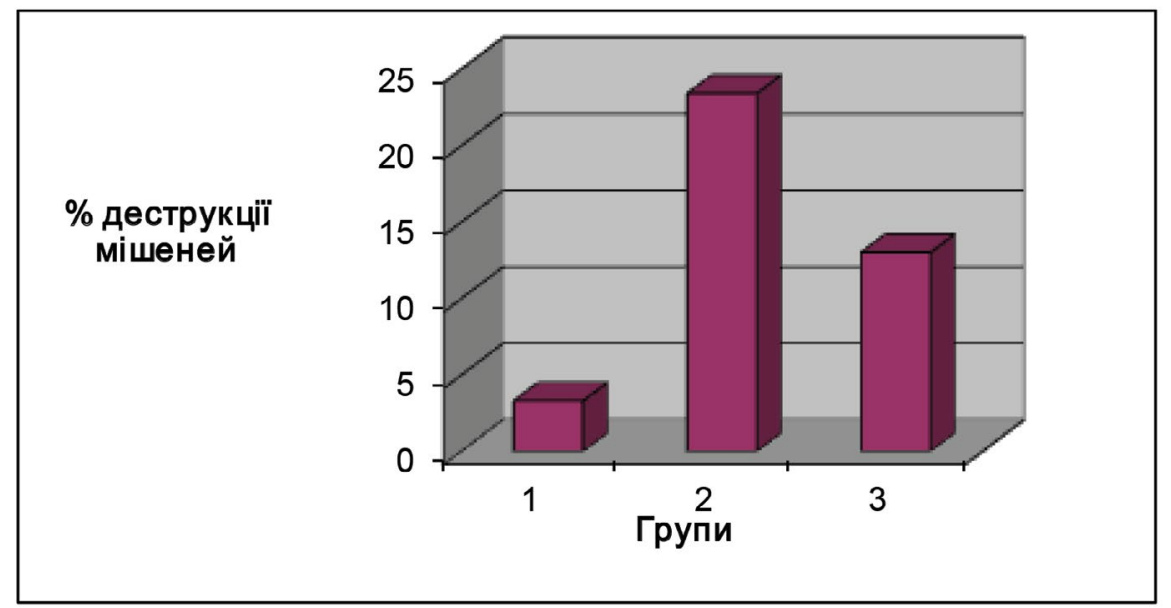

1 група - інтактні тварини; 2 група - сенсибілізовані тварини, які не лікуються; 3 група - сенсибілізовані тварини, які отримували СЕГД.

Рисунок 1. Активність специфічних цитолітичних клітин крові тварин різних груп.

\section{Обговорення.}

Дослідження рівня продукції ФГМ клітинами крові різних груп дозволило встановити, що у сенсибілізованих тварин мало місце істотні зміни індексу гальмування міграції макрофагів, тоді як у інтактних тварин не виявлялася продук- 
ція ФГМ при контакті лімфоцитів периферичної крові з алергеном. Проведення у сенсибілізованих тварин експериментальної терапії істотно знижувало активність продукції ФГМ, що може свідчити про певний десенсибілізуючий ефект від застосування препарату СЕГД (таблиця 3).

\section{Активність продукції ФГМ клітинами крові тварин різних груп}

Таблиця 3

\begin{tabular}{|c|c|c|c|c|}
\hline \multirow{3}{*}{ Групи } & \multicolumn{3}{|c|}{ Індекс гальмування міграції макрофагів } & \multirow{3}{*}{$\begin{array}{l}\text { Достовірність } \\
\text { відмінностей }\end{array}$} \\
\hline & \multicolumn{3}{|c|}{ Статистичні показники } & \\
\hline & Середнє & $\begin{array}{l}\text { Середнє квадратичне } \\
\text { відхилення }\end{array}$ & $\begin{array}{c}\text { Число } \\
\text { спостережень }\end{array}$ & \\
\hline 1. Інтактні тварини & 1,14 & $\pm 0,09$ & 7 & Вихідний рівень \\
\hline $\begin{array}{l}\text { 2. Сенсибілізовані тварини, } \\
\text { які не лікуються }\end{array}$ & 0,61 & $\pm 0,03$ & 7 & $<0,01$ \\
\hline $\begin{array}{l}\text { 3. Сенсибілізовані тварини, } \\
\text { які отримували СЕГД }\end{array}$ & 0,75 & $\pm 0,055$ & 7 & $<0,05$ \\
\hline
\end{tabular}

Визначали вміст антитіл до овальбуміну у сироватці крові і екстрактах з бронхолегеневої тканини експериментальних тварин. При дослідженні рівня антитіл титрували антитіла до овальбуміну у реакції пасивної гемаглютинації (переважно антитіла класу G і в тестуванні непрямої дегрануляції досліджували вміст антитіл класу E).

Вивчення вмісту IgE у сироватці крові і екстрактах з тканини легенів і бронхів показало (та- блиця 4, рисунок 2), що в умовах сенсибілізації у бронхолегеневій тканині збільшується кількість реагінів, що свідчить про можливий IgEопосередкований механізм модельної алергії на овальбумін. Рівень реагінів у сироватці крові також виявив достовірну тенденцію до підвищення, проте коефіцієнт дегрануляції над контролем був нижчим, що може свідчити про нижчий вміст антитіл цього класу у сироватці крові у порівнянні з бронхолегеневою тканиною.

\section{Вміст IgЕ-антитіл в екстрактах із бронхолегеневої тканини і сироватці крові тварин різних груп ( $\mathrm{M} \pm \mathrm{m})$}

\begin{tabular}{|l|c|c|}
\hline \multicolumn{1}{|c|}{ Групи } & \multicolumn{2}{c|}{ Коефіцієнт дегрануляції } \\
\cline { 2 - 3 } & Екстракт тканини & Сироватка \\
\hline 1. Інтактні тварини & $1,66 \pm 0,01$ & $2,32 \pm 0,09$ \\
\hline 2. Сенсибілізовані тварини, які не лікуються & $3,64^{\star \star} \pm 0,02$ & 2,01 \\
\hline 3. Сенсибілізовані тварини, які отримували СЕГД & $1,69 \pm 0,01$ & 0,01 \\
\hline
\end{tabular}

Примітки: - достовірно $(\mathrm{p}<0,05)$ по відношенню до контролю;

** - достовірно по відношенню $(p<0,02)$ до контролю.

Проведення експериментальної терапії у пе- ло до зниження рівня специфічних IgE антитіл як ріод дозволяючих інгаляцій алергену призводи- в екстрактах з тканини, так і у сироватці крові.

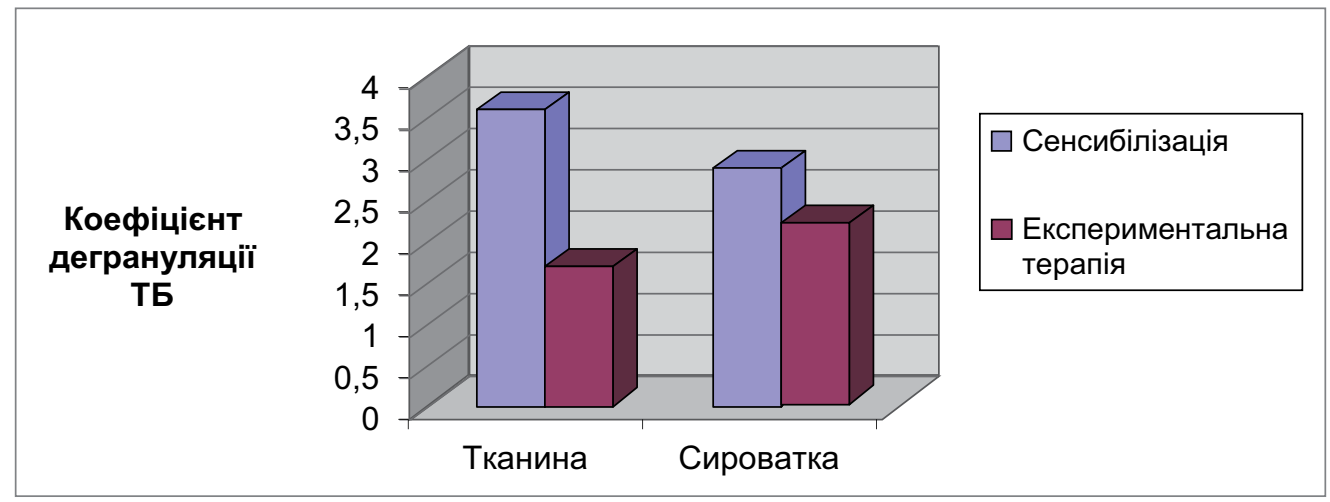

1 група - інтактні тварини; 2 група - сенсибілізовані тварини, які не лікуються; 3 група - сенсибілізовані тварини, які отримували СЕГД.

Рисунок 2. Вплив експериментальної терапії СЕГД на вміст реагінів у бронхолегеневій тканині і сироватці крові тварин з алергічними реакціями на овальбумін. 


\section{Висновки.}

Таким чином, проведені дослідження свідчать, що:

1. Представлена модель алергії у бронхолегеневій тканині із застосуванням у вигляді алергену яєчного альбуміну відтворена і може служити базою для випробування нових антиалергічних засобів.

2. Алергічні реакції в дихальних шляхах, що індукуються із застосуванням овальбуміну, носять змішаний характер по механізмах розвитку: разом з IgЕ антитілами до овальбуміну виявляються специфічні клітинні реакції.

3. При вивченні клітинних показників експериментальної моделі БА звертають на себе увагу флуктуації еозинофілів і паличкоядерних лейкоцитів периферичної крові експериментальних тварин. В період моделювання процесу спостерігалося достовірне збільшення кількості еозинофілів в усіх трьох групах тварин, тоді як кількість паличкоядерних лейкоцитів достовірно знижувалася у тварин 2-ї та 3-ї груп.

4. При дослідженні неспецифічних чинників імунітету кількісний показник фагоцитарної активності (фагоцитарне число) мав недостовірну тенденцію до зниження у тварин з модельованою алергією як при проведенні експериментальної терапії, так і без неї. Проте в цій моделі за відсутності змін в кількісній характеристиці клітин (моноцити, сегментоядерні лейкоцити), що фагоцитують, ї функціональна активність в умовах сенсибілізації може змінюватися, про що свідчать достовірні зміни у рівні фагоцитарного індексу.

5. При дослідженні активності специфічних клітинних реакцій, зокрема продукції фактору гальмування міграції макрофагів при контакті лімфоцитів крові щурів з овальбуміном in vitro, виявлено істотне підвищення цитолітичної активності клітин крові сенсибілізованих тварин у порівнянні 3 контролем. Проведення експериментальної терапії сприяло достовірному $(p<0,01)$ зниженню рівня деструктивної активності клітин крові, тобто застосування СЕГД сприяло зниженню сенсибілізації.

6. Вивчення вмісту антитіл до овальбуміну у сироватці крові і екстрактах з тканини легенів і бронхів експериментальних тварин показало, що в умовах сенсибілізації у сироватці крові і бронхолегеневій тканині збільшується кількість реагінів, що свідчить про можливість IgE- опосередкованого механізму модельної алергії на овальбумін. При цьо- му рівень сироваткового IgE був нижчим у порівнянні 3 бронхолегеневою тканиною. Проведення експериментальної терапії призводило до зниження рівня ОА-специфічних $\operatorname{lgE~антитіл~як~в~екстрактах~з~тканини,~так~і~у~}$ сироватці крові.

7. Використання препаратів СЕГД в період введення дозволяючої дози алергену сприяє зниженню сенсибілізації лабораторних тварин, що визначає перспективність клінічного використання препаратів при лікуванні хворих бронхіальною астмою.

\section{СПИСОК ЛІТЕРАТУРИ}

1. Актуальні питання алергології в практиці сімейного лікаря: навчальний посібник для лікарів - інтернів і лікарів слухачів закладів (факультетів) післядипломної освіти /за редакцією академіка НАМН України, проф. Вороненко Ю.В., проф.Шекери О.Г., проф.Кузнецової Л.В. // Ю. В. Вороненко, О. Г. Шекера, Л. В. Кузнецова, В. І. Літус, О. В. Назар, Т. М. Бондаренко, О. П. Назаренко, В. Д. Бабаджан, Н. В. Медведовська. - К.:Видавець Заславський О.Ю., 2016. 324 с. (Серія «Сімейна медицина»)

2. Алергологія // Під редакцією д.м.н., професора Кузнецової Л. В. - Київ, 2008. $365 \mathrm{c}$.

3. Біловол О. М. Клінічна імунологія та алергологія: навчальний посібник медичних ВНЗ IV рівня акредитації та медичних факультетів університетів / за редакцією: член-кореспондента АМНУ, Д.М.н., професора О.М. Біловола, д.м.н., професора П.Г. Кравчуна, д.м.Н., професора В.Д. Бабаджана. д.м.н., професора Л.В. Кузнецової) // О. М. Біловол, П. Г. Кравчун, В. Д. Бабаджан, Л. В. Кузнецова [та ін.] Харків «Гриф», 2011. - 549 с.

4. «Імунологія»: Підручник за редакцією д.м.н., професора Л.В.Кузнецової, д.м.н., професора В.Д.Бабаджана, д.м.н., професора В.І.Літус. Затверджено Міністерством освіти і науки, молоді та спорту України як підручник для лікарів - курсантів післядипломної освіти, лікарів - інтернів і студентів вищих медичних навчальних закладів ІУ рівня акредитації. Рекомендовано вченою радою НМАПО імені П.Л.Шупика як підручник (протокол № 5 від 2015 р.) - ТОВ «Меркьюрі-Поділля», 2015 - 584 с.

5. Клінічна та лабораторна імунологія: Національний підручник //За загальною редакцією доктора медичних наук, професора Кузнецової Л.В., доктора медичних наук, професора Бабаджана В.Д., доктора 
медичних наук, професора Фролова В.М. К.ООО. “Полиграф плюс" - Київ, 201. 2 922 с.: ил.

6. Літус В. І. Система імунітету за умов мікромеркуріалізму та його корекції // В. І. Літус, Ю. Б. Чайковський. - Монографія. - Київ, Інтерсервіс. - 2013. - 294 с.

7. Самченко І. І., Кірошка Б. Б., Грошова М. І., Бондаренко Т. П. Стан гіперактивності дихальних шляхів морської свинки за моделлю бронхіальної астми при трансплантації органотипічної культури надниркових залоз //Біологічний вісник. 2007 р.; 11 (1): 67-72.

8. Самченко І. І., Кірошка Б. Б., Сирота Б. Б., Грошова М. І., Бондаренко Т. П. Дозозалежний вплив овальбуміну та дексаметазону на ступінь алергічного запалення у морських свинок //Вісник Харківського національного університету імені В. Н. Каразіна. Серія: Біологія. 2010 р.; 11 (905): 201-5.

9. Чучалін А. Г. Бронхіальна астма: глобальна стратегія //Терапевтичний архів. 1994; 3: 3-8.

10. Андерссон П. Антиген-індукована бронхіальна анафілаксія у активно чутливих морських свинок //Алергія. 1980; 35 (1): 65-71.

11. Барнс P. Патофізіологія астми // Бразильський журнал «Клінічна фармакологія». 1996; 42: 3-10.

12. Касахара Д. І., Перини А., Лопес Ф. Д. та ін. Вплив сальбутамолу на легеневу чутливість при хронічному легеневому алергічному запаленні у морських свинок //Бразильський журнал медичних та біологічних досліджень. 2005 р.; 38: 723

13. Меншикова Б. Б. Методи лабораторних досліджень у клініці: Навчальний посібник. М.: Медицина. 1987; 368 с.

\section{РЕЗЮMЕ}

\section{ДОСЛІДЖЕННЯ ПОКАЗНИКІВ ІМУНІТЕТУ НА МОДЕЛІ БРОНХІАЛЬНОЇ АСТМИ У ЛАБОРАТОРНИХ ТВАРИН (ЩУРИ) ПРИ ДІЇ СТАНДАРТИЗОВАНОГО ЕКСТРАКТУ ЛИСТЯ РЕЛІКТОВОГО ДЕРЕВА ГІНКГО ДВОЛОПАТЕВОГО}

Кузнєцова Л.В. ${ }^{1}$, Літус В.І. ${ }^{1}$, Бабаджан В.Д. ${ }^{2}$, Юркіна А.В. ${ }^{1}$, Назар О.В. ${ }^{1}$, Бондаренко Т.М. ${ }^{1}$, Кузнєцов О.Г. ${ }^{1}$

${ }^{1}$ Національна медична академія післядипломної освіти (НМАПО) імені П. Л. Шупика, Київ

${ }^{2}$ Харківський національний медичний університет

Вступ. На відміну від численних випадків хвороби у людини, алергічна астма не розвивається в тваринному світі, тому виникає необхідність виявлення декількох характерних ознак астми у тварин.
Матеріали і методи. На моделі БА досліджували дію на лабораторних тваринах стандартизованого екстракту листя реліктового дерева гінкго дволопатевого (СЕГД). Після 2-кратної сенсибілізації щурам з 1-ої по 24 добу вводили через рот водний екстракт СЕГД у дозі 20 мг/кг/добу. Після закінчення останньої інгаляції у імунізованих і інтактних тварин досліджували реакції клітинного і гуморального імунітету.

Результати. Вивчали дослідження показників імунітету на моделі бронхіальної астми у лабораторних тварин (щури) при дії стандартизованого екстракту листя реліктового дерева гінкго дволопатевого (СЕГД). Дослідження фагоцитарної активності клітин периферичної крові щурів показало, що фагоцитарне число мало стійку тенденцію до зниження у тварин з модельованою алергією, як при проведенні експериментальної терапії, так і без неї. Використання препаратів СЕГД у період введення дозволяючої дози алергену сприяє зниженню сенсибілізації лабораторних тварин, що визначає перспективність клінічного використання препаратів при лікуванні хворих на бронхіальну астму.

Обговорення. Проведення у сенсибілізованих тварин експериментальної терапії істотно знижувало активність продукції ФГМ, що може свідчити про певний десенсибілізуючий ефект від застосування препарату СЕГД.

Висновки. Представлена модель алергії у бронхолегеневій тканині із застосуванням у вигляді алергену яєчного альбуміну відтворена і може служити базою для випробування нових антиалергічних засобів.

Ключові слова: бронхіальна астма, стандартизований екстракт листя реліктового дерева гінкго дволопатевого, овальбумін, щури.

\section{РЕЗЮMЕ}

\section{ИССЛЕДОВАНИЕ ПОКАЗАТЕЛЕЙ ИММУНИТЕТА НА МОДЕЛИ БРОНХИАЛЬНОЙ АСТМЫ У ЛАБОРАТОРНЫХ ЖИВОТНЫХ (КРЫСЫ) ПРИ ВОЗДЕЙСТВИИ СТАНДАРТИЗИРОВАННОГО ЭКСТРАКТА ЛИСТЬЕВ РЕЛИКТОВОГО ДЕРЕВА ГИНКГО ДВУЛОПАСТНОГО}

Кузнецова Л.В. ${ }^{1}$, Литус В.И. ${ }^{1}$, Бабаджан В.Д. ${ }^{2}$, Юркина А. В. ${ }^{1}$, Назар О.В. ${ }^{1}$, Бондаренко Т.Н. ${ }^{1}$, Кузнецов А.Г. ${ }^{1}$

${ }^{1}$ Национальная медицинская академия последипломного образования (НМАПО) имени П.Л. Шупика, Киев

${ }^{2}$ Харьковский национальный медицинский университет

Вступление. В отличие от многочисленных случаев болезни у человека, аллергическая астма не развивается в животном мире, поэтому возникает необходимость выявления нескольких характерных признаков астмы у животных.

Материалы и методы. На модели БА исследовали действие на лабораторных животных стандартизированного экстракта листьев реликтового дерева гинкго билоба (СЭГД). После 2-кратной сенсибилизации крысам с первого по 24 день вводили через рот водный экстракт СЭГД в дозе 20 мг/кг/сут. После окончания последней ингаляции у иммунизированных и интактных животных исследовали реакции клеточного и гуморального иммунитета. 
Результаты. Изучали исследования показателей иммунитета на модели бронхиальной астмы у лабораторных животных (крысы) при воздействии стандартизированного экстракта листьев реликтового дерева гинкго билоба (СЭГД). Исследование фагоцитарной активности клеток периферической крови крыс показало, что фагоцитарное число имело устойчивую тенденцию к снижению у животных с моделируемой аллергией, как при проведении экспериментальной терапии, так и без нее. Использование препаратов СЭГД в период введения разрешающей дозы аллергена способствует снижению сенсибилизации лабораторных животных, определяет перспективность клинического использования препаратов при лечении больных бронхиальной астмой.

Обсуждение. Проведение у сенсибилизированных животных экспериментальной терапии существенно снижало активность продукции ФТМ, что может свидетельствовать об определенном десенсибилизирующем эффекте от применения препарата СЭГД.

Выводы. Представленная модель аллергии в бронхолегочной ткани с применением в виде аллергена яичного альбумина имеет место и может служить базой для испытания новых антиаллергических средств.

Ключевые слова: бронхиальная астма, стандартизированный экстракт листьев реликтового дерева гинкго билоба двулопастного, овальбумин, крысы.

\section{SUMMARY}

\section{RESEARCH OF IMMUNITY INDICATORS ON MODELS OF BRONCHIAL ASTHMA IN LABORATORY ANIMALS (RATS) UNDER THE INFLUENCE OF A STANDARDIZED EXTRACT OF LEAVES OF A RELICA BUNCH}

Kuznetsova L. ${ }^{1}$, Litus V.1, Babadzhan V. ${ }^{2}$, Yurkina A. ${ }^{1}$, Nazar O. ${ }^{1}$, Bondarenko T. ${ }^{1}$, Kuznetsov A. ${ }^{1}$

${ }^{1}$ National Medical Academy of Postgraduate Education (NMAPE) named after P.L. Shupik, Kyiv

${ }^{2}$ National Medical University, Kharkiv

Introduction. Unlike many cases of the disease in humans, allergic asthma does not develop in the animal kingdom, so there is a need to identify several characteristic signs of asthma in animals.
Materials and methods. Using a BA model, we studied the effect on laboratory animals of a standardized extract of leaves of the relict tree of ginkgo biloba (SEGB). After 2-fold sensitization, rats from the first to the 24th day were injected with an aqueous extract of SEGB at a dose of $20 \mathrm{mg} / \mathrm{kg} /$ day. After the last inhalation in immunized and intact animals, the reactions of cellular and humoral immunity were studied.

Research results. Studied studies of immunity indicators on a model of bronchial asthma in laboratory animals (rats) under the influence of a standardized extract of leaves of the relict tree of ginkgo biloba (SEGB). A study of the phagocytic activity of rat peripheral blood cells showed that the phagocytic number tended to decrease in animals with simulated allergies, both during experimental therapy and without it. The use of SEGB preparations during the administration of a permissible dose of allergen helps to reduce the sensitization of laboratory animals, and determines the prospects for the clinical use of drugs in the treatment of patients with bronchial asthma.

Discussion of research. Conducting experimental therapy in sensitized animals significantly reduced the activity of MTF production, which may indicate a certain desensitizing effect from the use of the SEGB preparation.

Conclusions. The presented model of allergy in bronchopulmonary tissue using egg albumin as an allergen takes place and can serve as a basis for testing new anti-allergic drugs.

Key words: bronchial asthma, standardized extract of leaves of the relict tree of Ginkgo biloba bilobate, ovalbumin, rats.

\section{АВТОРСЬКА ДОВІДКА:}

\footnotetext{
- Кузнєцова Лариса Володимирівна професор кафедри клінічної, лабораторної імунології та алергології Національної медичної академії післядипломної освіти (НМАПО) імені П.Л. Шупика, доктор медичних наук, професор Адреса: вул. Дорогожицька, 9, м. Київ, 04112, Україна моб.: +380509952057 e-mail: nmapo_immun@ukr.net
}

\author{
- Кузнецова Лариса \\ Владимировна \\ профессор кафедры клинической, лаборатор- \\ ной иммунологии и аллергологии Националь- \\ ной медицинской академии последипломно- \\ го образования (НМАПО) имени П.Л. Шупика, \\ доктор медицинских наук, профессор \\ Адрес: ул. Дорогожицкая, 9, Киев, 04112, \\ Украина \\ моб.: +380509952057 \\ e-mail: nmapo_immun@ukr.net
}

\section{- Kuznetsova Larisa}

Professor of the Department of Clinical, Laboratory Immunology and Allergology of the National Medical Academy of Postgraduate Education (NMAPE) named after P.L. Shupik, Doctor of Medical Sciences, Professor Address: st. Dorogozhytska, 9, Kyiv, 04112, Ukraine mob.: +380509952057 e-mail: nmapo_immun@ukr.net 


\section{- Літус Віктор Іванович}

завідувач кафедри клінічної, лабораторної імунології та алергології Національної медичної академії післядипломної освіти (НМАПО) імені П.Л. Шупика, доктор медичних наук, професор

Адреса: вул. Дорогожицька, 9 ,

м. Київ, 04112, Україна

моб.: +380503101827

e-mail: nmapo_immun@ukr.net

- Бабаджан Володимир Данилович професор кафедри внутрішньої медицини № 2, клінічної імунології та алергології імені академіка Л.Т. Малої Харківського національного медичного університету, доктор медичних наук, професор Адреса: проспект Науки, 4, м. Харків, 61022, Україна моб.: +380675732338 e-mail: vladdoc2@gmail.com

\section{- Юркіна Алла Валеріївна}

асистент кафедри клінічної, лабораторної імунології і алергології Національної медичної академії післядипломної освіти (НМАПО) імені П.Л. Шупика

Адреса: вул. Дорогожицька, 9,

м. Київ, 04112, Україна

моб.: +380677628907

e-mail: nmapo immun@ukr.net

\section{- Назар Олег Володимирович} доцент кафедри клінічної, лабораторної імунології та алергології Національної медичної академії післядипломної освіти (НМАПО) імені П.Л. Шупика, кандидат медичних наук, доцент

Адреса: вул. Дорогожицька, 9

м.Київ, 04112, Україна

моб.: +380677040948

e-mail: nmapo_immun@ukr.net

\section{- Бондаренко Тетяна Миколаївна} доцент кафедри клінічної, лабораторної імунології та алергології Національної медичної академії післядипломної освіти (НМАПО) імені П.Л. Шупика, кандидат медичних наук Адреса: вул. Дорогожицька, 9,

м.Київ, 04112, Україна

моб.: +380676360309

e-mail: tanysheh@gmail.com

\section{- Кузнецов Олексій Геннадійович}

асистент кафедри клінічної, лабораторної імунології та алергології Національної медичної академії післядипломної освіти (НМАПО) імені П.Л. Шупика

Адреса: вул. Дорогожицька, 9 ,

м.Київ, 04112, Україна

моб.: +380671324040

e-mail: nmapo_immun@ukr.net
- Литус Виктор Иванович заведующий кафедрой клинической, лабораторной иммунологии и аллергологии Национальной медицинской академии последипломного образования (НМАПО) имени П.Л. Шупика, доктор медицинских наук, профессор

Адрес: ул. Дорогожицкая, 9,

Киев, 04112, Украина

моб.: +380503101827

e-mail: nmapo immun@ukr.net

- Бабаджан Владимир Данилович профессор кафедры внутренней медицины № 2, клинической иммунологии и аллергологии имени академика Л.Т. Малой Харьковского национального медицинского университета, доктор медицинских наук, професор Адрес: проспект Науки, 4,

Харьков, 61022, Украина

моб.: +380675732338

e-mail: vladdoc2@gmail.com

\section{- Юркина Алла Валерьевна} ассистент кафедры клинической, лабораторной иммунологии и аллергологии Национальной медицинской академии последипломного образования (НМАПО) имени П.Л. Шупика Адрес: ул. Дорогожицкая, 9,

Киев, 04112, Украина

моб.: +380677628907

e-mail: nmapo immun@ukr.net

\section{- Назар Олег Владимирович} доцент кафедры клинической, лабораторной иммунологии и аллергологии Национальной медицинской академии последипломного образования (НМАПО) имени П.Л. Шупика, кандидат медицинских наук, доцент Адрес: ул. Дорогожицкая, 9, Киев, 04112, Украина моб.: +380677040948

e-mail: nmapo_immun@ukr.net

\section{- Бондаренко Татьяна Николаевна} доцент кафедры клинической, лабораторной иммунологии и аллергологии Национальной медицинской академии последипломного образования (НМАПО) имени П.Л. Шупика, кандидат медицинских наук Адрес: ул. Дорогожицкая, 9,

Киев, 04112, Украина

моб.: +380676360309

e-mail: tanysheh@gmail.com

- Кузнецов Алексей Геннадьевич ассистент кафедры клинической, лабораторной иммунологии и аллергологии Национальной медицинской академии последипломного образования (НМАПО) имени П.Л. Шупика Адрес: ул. Дорогожицкая, 9,

Киев, 04112, Украина

моб.: +380671324040

e-mail: nmapo_immun@ukr.net

\section{- Litus Viktor}

Head of the Department of Clinical, Laboratory Immunology and Allergology of the National Medical Academy of Postgraduate Education (NMAPE) named after P.L. Shupik, Doctor of Medical Sciences, Professor Address: st. Dorogozhytska, 9 , Kyiv, 04112, Ukraine mob.: +380503101827

e-mail: nmapo_immun@ukr.net

\section{- Babadzhan Volodymyr}

Professor, Department of Internal Medicine No. 2, Clinical Immunology and Allergology named after Academician L.T. Malaya, Kharkov National Medical University, Doctor of Medical Sciences, Professor Address: 4 Nauki Avenue, Kharkiv, 61022, Ukraine mob.: +380675732338 e-mail: vladdoc2@gmail.com

\section{- Yurkina Alla}

assistant of the Department of Clinical, Laboratory Immunology and Allergology of the National Medical Academy of Postgraduate Education (NMAPE) named after P.L. Shupik Address: st. Dorogozhytska, 9, Kyiv, 04112, Ukraine mob.: +380677628907 e-mail: nmapo immun@ukr.net

\section{- Nazar Oleg}

Associate Professor of the Department of Clinical, Laboratory Immunology and Allergology of the National Medical Academy of Postgraduate Education (NMAPE) named after P.L. Shupik, Candidate of Medical Sciences, Associate Professor Address: st. Dorogozhytska, 9,

Kyiv, 04112, Ukraine

mob.: +380677040948

e-mail: nmapo_immun@ukr.net

\section{- Bondarenko Tetiana}

associate professor of the Department of Clinical, Laboratory Immunology and Allergology of the National Medical Academy of Postgraduate Education (NMAPE) named after P.L. Shupik, candidate of medical sciences Address: st. Dorogozhytska, 9, Kyiv, 04112, Ukraine mobile phone: +380676360309 e-mail: tanysheh@gmail.com

\section{- Kuznetsov Oleksii}

assistant of the Department of Clinical, Laboratory Immunology and Allergology of the National Medical Academy of Postgraduate Education (NMAPE) named after P.L. Shupik Address: st. Dorogozhytska, 9,

Kyiv, 04112, Ukraine mob.: +380671324040 e-mail: nmapo_immun@ukr.net 